\title{
STRATEGI PERDAGANGAN TUNA INDONESIA KE PASAR UNI EROPA
}

\author{
Eko Sri Wiyono ${ }^{1 *}$ Akhmad Solihin ${ }^{2}$ \\ ${ }^{1}$ Departemen Pemanfaatan Sumberdaya Perikanan, Fakultas Perikanan dan Ilmu Kelautan \\ Institut Pertanian Bogor (IPB), Bogor 16680 \\ ${ }^{2}$ Pusat Kajian Sumberdaya Pesisir dan Lautan, Institut Pertanian Bogor, Bogor 16134 \\ "Email: eko_ipb@yahoo.com
}

\begin{abstract}
RINGKASAN
Peningkatan pertumbuhan penduduk dunia menuntut pasokan kebutuhan pangan, salah satunya dari protein ikan dari penangkapan ikan. Tekanan terhadap perikanan tangkap tersebut mengakibatkan gejala tangkap lebih yang disertai dengan masih tingginya angka kegiatan praktik perikanan ilegal. Dampak perikanan ilegal disikapi secara serius oleh masyarakat dunia dengan ditetapkannya berbagai instrumen internasional, baik yang mengikat maupun tidak. Sementara itu, komunitas Uni Eropa membuat peraturan khusus yang mengatur perdagangan ikan yang bebas dari praktik perikanan ilegal. Tujuan penelitian ini yaitu: (1) menganalisis aturan Uni Eropa; (2) menganalisis level kompatibilitas peraturan Indonesia dengan peraturan Uni Eropa; dan (3) menyusun strategi perdagangan tuna Indonesia di pasar Uni Eropa. Metode yang digunakan analisis hukum dan A'WOT. Analisa hukum mengungkapkan bahwa untuk memberantas perikanan ilegal, Uni Eropa mengeluarkan Peraturan Dewan No 1005/2008, yang disikapi oleh Pemerintah Indonesia dengan cara mengeluarkan Peraturan Menteri Kelautan dan Perikanan Nomor Per.13/MEN/2012 tentang Sertifikasi Hasil Tangkapan Ikan. Sementara A'WOT menghasilkan strategi, yaitu: monitoring dan evaluasi implementasi Sertifikat Hasil Tangkapan Ikan berkala; sosialisasi pemerataan SHTI di pelabuhan perikanan, dan penataan sistem data terpadu.
\end{abstract}

Kata kunci: perikanan illegal, Uni Eropa, sertifikat hasil tangkapan ikan

\section{PERNYATAAN KUNCI}

- Perikanan ilegal tidak hanya merugikan perekonomian suatu negara pantai (coastalstate) akan tetapi juga mengakibatkan kerusakan ekosistem laut, khususnya gejala tangkap lebih (over fishing), baik yang terjadi di suatu negara pantai maupun laut lepas (bigh seas).
- Regulasi Uni Eropa sangat ketat dalam pemberantasan Ilegal Unreported and Unregulated (IUU) Fishing sehingga berdampak terhadap perdagangan perikanan tuna Indonesia ke pasar Uni Eropa.

- Jumlah dan nilai perdagangan perikanan, khususnya spesies tuna ke Negara-negara Uni Eropa cukup besar sehingga Pemerintah 
Indonesia perlu mengadopsi regulasi Uni Eropa tersebut dalam peraturan nasional.

\section{REKOMENDASI KEBIJAKAN}

- Revisi peraturan Indonesia mengenai kewajiban pengisian log penangkapan ikan. Hal ini dikarenakan, pengisian hasil tangkapan ikan dilakukan oleh juragan darat atau pengurus kapal ikan di pelabuhan perikanan. Selain itu, diperlukan sosialisasi secara berkala oleh pihak pelabuhan perikanan.

- Monitoring dan evaluasi hasil implementasi Sertifikat Hasil Tangkapan Ikan (SHTI) berkala. Hal ini bertujuan apakah ditemukan kendala dalam proses pengisian logbook penangkapan ikan dan proses permohonan SHTI, baik yang diajukan oleh nelayan dalam mendapatkan lembar awal dan oleh pihak pembeli/pengolah ikan dalam mendapatkan lembar turunan.

- Penataan sistem data terpadu, dalam bentuk penyiapan sumber daya manusia atau personil dalam penyiapan formulir SHTI dan perbaikan jaringan internet dalam menjamin kelencaran informasi kepada pasar di Uni Eropa.

\section{PENDAHULUAN}

Perikanan dunia dihadapkan pada isu kelangkaan, yang dicerminkan dengan penurunan produksi tangkapan laut. FAO (2010) melaporkan bahwa produksi perikanan laut dunia berfluktuasi antara 77 dan 86 juta ton dengan catatan tertinggi 86,8 juta ton pada tahun 2000 dan menurun menjadi 79,9 juta ton pada tahun 2009. Laporan FAO (2016) mencatat produksi perikanan tangkap dunia pada tahun 2014 adalah sebesar 93,4 juta ton. Peningkatan tersebut tidak dapat dilepaskan dari peningkatan kebutuhan protein hewani, yang dikhawatirkan menimbulkan gejala tangkap lebih (overfishing).

Ancaman kelangkaan perikanan dunia diperkuat dengan penelitian Worm et.al (2006), yang mengungkapkan bahwa pada tahun 2048 akan terjadi kehancuran perikanan global. Namun demikian, penelitian Worm tersebut dibantah oleh Branch (2008), karena dianggap mengabaikan berbagai faktor, salah satunya adalah regulasi internasional dan nasional dalam mewujudkan perikanan dunia yang berkelanjutan. Terlepas dari perdebatan para pakar perikanan dunia tersebut, peningkatan konsumsi ikan seiring dengan bertambahnya jumlah penduduk dunia telah mendorong negara produsen ikan untuk meningkatkan teknologinya dalam menciptakan alat penangkap ikan yang efektif dan efisien, sehingga semakin menekan kelestarian sumberdaya ikan. Laporan FAO (1998) memperkirakan akan terjadinya kekurangan pasokan ikan sebesar 62,4 juta ton pada tahun 2020 karena permintaan terhadap protein ikan yang semakin meningkat (DKP, 2007).

Ancaman krisis perikanan dunia tersebut juga dihadapkan pada permasalahan Illegal Unreported Unregulated Fishing (IUU Fishing), yang meliputi: illegal (kegiatan yang tidak sah); unreported (kegiatan yang tidak dilaporkan); dan unregulated (kegiatan yang tidak atau belum diatur). Kegiatan IUU Fishing dapat menyebabkan penurunan stok ikan.

Dampak IUU Fishing sebagaimana dipaparkan diatas, menuntut masyarakat global untuk mengatasi masalah ini. Untuk mewujudkan perikanan dunia yang berkelanjutan, maka ditetapkan berbagai instrumen internasional, baik yang mengikat (hardlaw) maupun tidak mengikat 
(softlaw), yaitu UNCLOS 1982, FAO Compliance Agreement 1993, UNIA 1995, PSM Agreement 2009, CCRF 1995, dan IPOA to Prevent, Deter and Eliminate Illegal, Unreported and Unregulated Fishing 2001.

Enam instrumen internasional tersebut diatas menjadi landasan berbagai negara untuk bergabung dalam suatu organisasi pengelolaan perikanan regional (regional fisheries management organization, RFMO) dalam mengatur kegiatan perikanan berkelanjutan di laut lepas. Konvensi pembentukan RFMO mengatur hak dan kewajiban setiap Negara anggota dalam menangkap ikan di laut lepas yang sudah dikelola RFMO, diantaranya adalah pengaturan perdagangan ikan yang bebas dari praktik-praktik IUU Fishing. Selain itu, komunitas Uni Eropa juga membuat peraturan khusus yang mengatur perdagangan ikan bebas IUU Fishing.

\section{SITUASI TERKINI}

- FAO memperkirakan kontrbusi illegal fishing mencapai 30 persen dari total tangkapan dunia, sedangkan Komisi Uni Eropa memperkirakan 15-20 persen (EFTEC, 2008). Sementara MRAG (2008) memperkirakan nilai global IUU Fishing mencapai US\$ 11 milyar (MRAG, 2008) dan Komisi Uni Eropa juga memperkirakan setiap tahun nilai global IUU Fishing sebesar US\$30 juta.

- Uni Eropa melakukan pemberantasan IUU Fishing melalui pendekatan rantai pasar (trade measures) dengan mengeluarkan European Council (EC) Regulation No. 1005/2008 of 29 September 2008 establishing a community system to prevent, deter and eliminate illegal, unreported and unregulated fishing. Pemerintah Indonesia mengadopsi regulasi Uni Eropa tersebut melalui Peraturan Menteri Kelautan dan Perikanan (Permen KP) Nomor Per.28/MEN/2009 tentang Sertifikasi Hasil Tangkapan Ikan (SHTI), yang kemudian dicabut oleh Permen KP No. Per.13/MEN/2012. Adapun tujuan SHTI, yaitu untuk: (a) memperlancar kegiatan perdagangan hasil tangkapan ikan dari laut oleh kapal penangkap ikan Indonesia dan/atau kapal penangkap ikan asing baik secara langsung maupun tidak langsung dipasarkan ke Uni Eropa; (b) membantu upaya nasional dan internasional dalam memberantas (menghindari, melawan dan memerangi) kegiatan IUU Fishing; (c) memastikan penelusuran (traceability) hasil tangkapan ikan pada tahapan penangkapan, pengolahan, pengangkutan dan pemasaran; dan (d) melaksanakan ketentuan konservasi dan pengelolaan sumberdaya perikanan secara berkelanjutan

- Nilai ekspor perikanan diantara negara-negara Uni Eropa empat kali lebih besar dari ekspor ke negara dunia ketiga. Pada tahun 2012, perdagangan intra Uni Eropa mencatat volume perdagangan dengan total lebih dari 5,1 juta ton (berat bersih) yang meningkat lebih dari 270.000 ton $(+5,6 \%)$ pada tahun 2011, dengan nilai total perdagangan intra Uni Eropa sebesar 17,9 miliar EUR (+8,5\%). Adapun komoditas perikana yang dikonsumsi masyarakat Uni Eropa, yaitu tuna, kod dan salmon.

- Ekspor perikanan tuna Indonesia ke Uni Eropa perlu diperkuat dengan berbagai kebijakan, karena besarnya jumlah dan nilai ekspor yang dicatat oleh Kementerian Kelautan dan Perikanan. Perbaikan kebijakan tersebut dilakukan terhadap pelaksanaan SHTI di lokasi 
pendaratan tuna terbesar, salah satunya Pelabuhan Benoa, Bali. Informasi yang diperoleh dari lokasi studi digunakan untuk analisis A'WOT yang mengkombinasikan SWOT dengan AHP.

\section{ANALISIS DAN ALTERNATIF SOLUSI}

\section{Regulasi Uni Eropa}

Peraturan Dewan (Council Regulation) (EC) No 1005/2008 tentang Sistem Komunitas untuk mencegah, menangkal dan menghilangkan IUU
Fishing. Instrumen Uni Eropa ini bertujuan untuk memberantas IUU Fishing yang memasuki pasar Uni Eropa, melalui pengaturan produk perikanan yang telah disertifikasi sebagai hukum oleh negara bendera atau negara ekspor yang bersangkutan. Berdasarkan hasil analisa, setidaknya terdapat 9 aturan pokok dalam aturan tersebut, yaitu aplikasi aturan untuk inspeksi kapal negara ketiga dan produk perikanan ke negara anggota Uni Eropa, Skema Sertifikasi Tangkapan, Sistem Kesiagaan Komunitas, Daftar Kapal IUU Komunitas, Daftar negara ketiga yang tidak bekerjasama, Tindakan darurat, Nasional Komisi Eropa, Sanksi, dan Penampakan di laut (Tabel 1).

Tabel 8. Council Regulation (EC) No 1005/2008

\begin{tabular}{|c|c|c|}
\hline No & Aturan & Tentang \\
\hline 1 & $\begin{array}{l}\text { Aplikasi aturan } \\
\text { untuk inspeksi kapal negara } \\
\text { ketiga dan produk perikanan } \\
\text { ke negara anggota Uni } \\
\text { Eropa }\end{array}$ & $\begin{array}{l}\text { - Pemberitahuan awal } \\
\text { - Transhipment } \\
\text { - Kewenangan memasuki pelabuhan di Uni Eropa } \\
\text { - Mencatat pendaratan dan operasi transhipment } \\
\text { - Inspeksi kapal ikan } \\
\text { - Pelanggaran }\end{array}$ \\
\hline 2 & $\begin{array}{l}\text { Skema Sertifikasi } \\
\text { Tangkapan }\end{array}$ & $\begin{array}{l}\text { - Konsentrasi produk } \\
\text { - } \text { Produk yang dikecualikan dari ruang lingkup regulasi IUU } \\
\text { - Konsentrasi aliran perdagangan } \\
\text { - Skema sertifikasi dan sarana transportrasi } \\
\text { - Transportasi tidak langsung produk perikanan dari negara } \\
\text { bendera kapal ke Uni Eropa melalui negara ketiga lainnya } \\
\text { - Transportasi tidak langsung tanpa pengolahan di negara ketiga } \\
\text { lainnya } \\
\text { - Transportasi langsung dengan pengolahan di negara ketiga } \\
\text { - lainnya } \\
\text { - Impor kiriman campuran } \\
\text { - Tanggal pelaksanaan sertifikasi tangkapan } \\
\text { - } \text { Pengungan ke skema sertikasi lainnya } \\
\text { - Penyederhanaan skema hasil tangkapan untuk produk perikanan } \\
\text { - dengtan karakteristik khusus } \\
\text { - } \text { kapema sertifikasi untuk produk perikanan yang diperoleh kapal- } \\
\text { - Prosedur kerbagai pihak yang terlibat dalam skema sertifikasi } \\
\text { - Pengakuan skema RFMO }\end{array}$ \\
\hline
\end{tabular}


Tabel 8. Lanjutan

\begin{tabular}{|c|c|c|}
\hline No & Aturan & Tentang \\
\hline & & $\begin{array}{l}\text { - Penggunaan sistem penelusuran elektronik untuk mengotrol } \\
\text { negara ketiga / } \\
\text { - Penggunaan system telusur di bawah kendali negara ketiga / } \\
\text { pengaturan khusus antara negara ketiga dan Komisi Eropa }\end{array}$ \\
\hline 3 & $\begin{array}{l}\text { Sistem Kesiagaan } \\
\text { Komunitas }\end{array}$ & $\begin{array}{l}\text { - Penerbitan Kesiagaan } \\
\text { - Aksi terkait Penerbitan Kesiagaan }\end{array}$ \\
\hline 4 & $\begin{array}{l}\text { Daftar Kapal IUU } \\
\text { Komunitas }\end{array}$ & $\begin{array}{l}\text { - Pendugaan IUU fishing } \\
\text { - Pembentukan daftar kapal IUU Fishing } \\
\text { - Penghapusan kapal ikan dari daftar kapal IUU fishing } \\
\text { - Isi, publikasi, dan pemeliharaan daftar kapal IUU fishing }\end{array}$ \\
\hline 5 & $\begin{array}{l}\text { Daftar negara ketiga yang } \\
\text { tidak bekerjasama }\end{array}$ & $\begin{array}{l}\text { - Identifikasi negara ketiga yang tidak bekerjasama } \\
\text { - Daftar kapal IUU yang diadopsi RFMO } \\
\text { - Pendekatan identifikasi negara ketiga yang tidak bekerjasama } \\
\text { - Menyusun daftar negara ketiga yang tidak bekerjasama } \\
\text { - Penghapusan dari daftar negara ketiga yang tidak bekerjasama } \\
\text { - Publikasi daftar negara ketiga yang tidak bekerjasama } \\
\text { - Tindakan darurat }\end{array}$ \\
\hline 6 & Tindakan darurat & $\begin{array}{l}\text { - Aksi terhadap kapal perikanan termasuk daftar kapal komunitas } \\
\text { IUU } \\
\text { - Aksi terhadap negara ketiga yang tidak bekerjasama }\end{array}$ \\
\hline 7 & Nasional Komisi Eropa & $\begin{array}{l}\text { - Dukungan nasional atau keterlibatan pada IUU Fishing } \\
\text { - Pencegahan dan sanksi } \\
\text { - Pelanggaran serius }\end{array}$ \\
\hline 8 & Sanksi & - Sanksi \\
\hline 9 & Penampakan di laut & $\begin{array}{l}\text { - Penyampaian informasi mengenai kapal kapal penangkap ikan } \\
\text { yang terlihat } \\
\text { - Investigasi terhadap kapal kapal penangkap ikan yang terlihat }\end{array}$ \\
\hline
\end{tabular}

Berdasarkan aturan pokok di atas, maka hal yang harus diperhatikan adalah Skema Sertifikasi Tangkapan, karena terkait dengan sistem sertifikasi hasil tangkapan ikan di Indonesia. Menurut Pasal 12 ayat (1), impor produk perikanan yang melakukan IUU Fishing dilarang masuk ke Uni Eropa. Untuk menjamin efektivitas larangan tersebut, produk-produk perikanan yang dikirim ke Uni Eropa harus disertai dengan sertikat yang diatur dalam regulasi (Pasal 12 ayat 2). Lebih lanjut dijelaskan pada Pasal 12 ayat (3), bahwa sertifikat hasil tangkapan tersebut harus disahkan oleh negara bendera kapal penangkap ikan, dimana sertifikat tersebut menyatakan bahwa hasil tangkapannya sesuai dengan hukum yang berlaku, regulasi dan tindakan konservasi dan pengelolaan internasional.

\section{Pelaksanaan Sertifikasi Hasil Tangkapan Ikan dalam Peraturan Indonesia}

Penetapan Council Regulation (EC) No 1005/2008 dalam pemberantasan IUU Fishing melalui jalur pemasaran ditindaklanjuti oleh Pemerintah Indonesia dengan cara mengeluarkan Peraturan Menteri Kelautan dan Perikanan (Permen KP) No. Per.13/MEN/2012 tentang Sertifikasi Hasil Tangkapan Ikan. Menurut Peraturan Menteri Kelautan dan Perikanan tersebut, SHTI adalah surat keterangan yang 
menyatakan bahwa hasil perikanan yang diekspor bukan dari kegiatan Illegal, Unreported, and Unregulated (IUU) Fishing.Regulasi EC No 1005/2008 hanya memuat SHTI-Lembar Awal dan SHTI-Lembar Turunan. Ketentuan tersebut tidak bisa dilakukan oleh Indonesia, karena dominasi nelayan-nelayan kecil yang tidak memiliki Bukti Pendaftaran Kapal (BPK) sebagai pengganti legalitas atas kepemilikan izin penangkapan ikan (Surat Izin Penangkapan Ikan/SIPI). Ketiadaan SIPI bagi nelayan besar atau BPK untuk nelayan kecil mengakibatkan ekspor tuna Indonesia ditolak oleh pasar Uni Eropa. Berdasarkan permasalahan tersebut, Permen KP No. Per.13/MEN/2012 mencabut Permen KP No Per.28/MEN/2009 yang hanya memuat SHTI-Lembar Awal dan Lembar Turunan.

Sertifikat Hasil Tangkapan Ikan digunakan sebagai kelengkapan dokumen ekspor untuk hasil tangkapan ikan di laut yang berasal dari kapal penangkap ikan Indonesia dan kapal penangkap ikan asing (Pasal 4 ayat 1). Adapun SHTI yang dimuat dalam Permen KP No. Per.13/MEN/ 2012 terdiri atas:

a. SHTI-Lembar Awal, adalah surat keterangan yang memuat informasi hasil tangkapan ikan yang didaratkan dari kapal penangkap ikan untuk tujuan pencatatan. SHTI Lembar Awal diterbitkan untuk hasil tangkapan ikan yang berasal dari kapal penangkap ikan dengan ukuran di atas 20 gross tonnage (GT).

b. SHTI-Lembar Turunan, adalah surat keterangan yang memuat informasi sebagian atau seluruh hasil tangkapan ikan sesuai dengan lembar awal sebagai dokumen yang menyertai hasil perikanan yang dipasarkan ke Uni Eropa. SHTI Lembar Turunan diterbitkan untuk hasil tangkapan ikan yang berasal dari kapal penangkap ikan dengan ukuran di atas 20 GT.

c. SHTI-Lembar Turunan Yang Disederhanakan, adalah surat keterangan yang memuat informasi seluruh atau sebagian hasil tangkapan ikan yang didaratkan dari kapal penangkap ikan sebagai dokumen yang menyertai hasil perikanan yang dipasarkan ke Uni Eropa. SHTI Lembar Turunan Yang Disederhanakan diterbitkan untuk hasil tangkapan ikan yang berasal dari kapal penangkap ikan dengan ukuran sampai dengan $20 \mathrm{GT}$.

Berdasarkan pengelompokkan SHTI diatas, mengakomodir permasalahan nelayan kecil yang tidak memiliki dokumen peizinan. Oleh karenanya, dalam Permen KP No. Per.13/MEN/2012 memuat SHTI-Lembar Turunan Yang Disederhanakan. Usulan Indonesia tersebut ditanggapi serius oleh Uni Eropa dengan membolehkan SHTI-Lembar Turunan Yang Disederhanakan yang sebelumnya tidak dikenal dalam EC No 1005/2008.

Selain SHTI di atas, terhadap hasil tangkapan ikan di laut dari kapal penangkap ikan asing yang masuk ke Unit Pengolahan Ikan (UPI) untuk diekspor kembali diterbitkan SHTI Impor. SHTI Impor adalah surat keterangan yang menyatakan bahwa hasil perikanan yang diekspor ke Uni Eropa menggunakan sebagian atau seluruh bahan baku ikannya berasal dari negara lain yang sudah menotifikasi Catch Certificate ke Uni Eropa.

Penerbitan SHTI melibatkan berbagai pihak sesuai dengan kewenangannya. Menurut Pasal 6, Menteri memberikan kewenangan pelaksanaan SHTI kepada Direktur Jenderal selaku Otoritas Kompeten. Sementara Direktur Jenderal selaku Otoritas Kompoten dalam pelaksanaan penerbitan SHTI mendelegasikan kepada Otoritas 
Kompeten Lokal, yang terdiri dari Kepala Pelabuhan Perikanan yang merupakan Unit Pelaksana Teknis (UPT) Kementerian, dan Kepala Pelabuhan Perikanan yang merupakan UPT Daerah. Otoritas Kompeten Lokal ditetapkan oleh Otoritas Kompeten. Adapun penetapan Otoritas Kompeten Lokal berdasarkan kriteria:

a. Pelabuhan Perikanan yang merupakan UPT Kementerian:

1) ikan yang didaratkan sebagian untuk tujuan ekspor;

2) terdapat UPI;

3) mempunyai sarana komunikasi yang memadai;

4) mempunyai Sumber Daya Manusia yang telah memiliki Sertifikat Bimbingan Teknis Sertifikasi Hasil Tangkapan Ikan; dan

5) terdapat Pengawas Perikanan.

b. Pelabuhan Perikanan yang merupakan UPT Daerah:

1) lokasinya relatif jauh dari Pelabuhan Perikanan yang merupakan UPT

2) Kementerian;

3) mempunyai sarana komunikasi yang memadai;

4) mempunyai Sumber Daya Manusia yang telah memiliki sertifikat Bimbingan Teknis Sertifikasi Hasil Tangkapan Ikan;

5) lokasinya relatif dekat dengan UPI/ eksportir; dan

6) telah terdapat Pengawas Perikanan.

Apabila Otoritas Kompeten Lokal berhalangan, maka penerbitan SHTI dilaksanakan oleh Pejabat Alternate yang ditetapkan oleh Otoritas Kompeten bersamaan dengan penetapan Otoritas Kompeten Lokal. Untuk dapat ditetapkan sebagai Pejabat Alternate harus memiliki Sertifikat Bimbingan Teknis Sertifikasi
Hasil Tangkapan Ikan (Pasal 8). Sementara itu, dalam pelaksanaan sertifikasi hasil tangkapan ikan, Otoritas Kompeten berkoordinasi dengan Direktur Jenderal Pengolahan dan Pemasaran Hasil Perikanan dan Direktur Jenderal Pengawasan Sumberdaya Kelautan dan Perikanan (Pasal 9 ayat 1). Pelaksanaan koordinasi Direktur Jenderal Pengolahan dan Pemasaran Hasil Perikanan mempunyai kewenangan: (a) melakukan komunikasi dengan otoritas terkait di luar negeri/otoritas kompeten negara importir/komisi Eropa yang berkaitan dengan SHTI; (b) melakukan notifikasi, antara lain: nama, specimen, Otoritas Kompeten dan Otoritas Kompeten Lokal penerbit SHTI dan perubahannya, Pejabat Alternate, dan perubahan SHTI; dan/atau (c) menyampaikan informasi berbagai perkembangan, peraturan dan informasi dari otoritas terkait di luar negeri/otoritas kompeten negara importir/komisi Eropa yang berkaitan dengan SHTI. Pelaksanaan koordinasi Direktur Jenderal Pengawasan Sumber Daya Kelautan dan Perikanan mempunyai kewenangan melakukan pengawasan terhadap kapal penangkap ikan dan menyampaikan hasilnya kepada Otoritas Kompeten.

Sementara itu, Syarat Dan Tata Cara Penerbitan SHTI dituangkan dalam Bab IV. Menurut Pasal 10, nakhoda, pemilik kapal, atau yang ditunjuk oleh pemilik kapal untuk mendapatkan SHTI-Lembar Awal, mengajukan permohonan kepada Otoritas Kompeten Lokal dengan melampirkan persyaratan sebagai berikut: (1) draft SHTILembar Awal; (2) fotokopi Identitas Pemohon; (3) fotokopi Surat Tanda Bukti Lapor Kedatangan Kapal; (4) fotokopi Surat Izin Penangkapan Ikan (SIPI); (5) laporan hasil verifikasi pendaratan ikan; dan (6) SKPI bagi kapal penangkap ikan yang mendaratkan ikan hasil tangkapan pada pelabuhan 
perikanan atau pelabuhan umum yang tidak ditetapkan sebagai Otoritas Kompeten Lokal.

Laporan hasil verifikasi pendaratan ikan diterbitkan oleh Pengawas Perikanan paling lama 2 (dua) hari setelah dilakukan verifikasi terhadap: nama kapal; nomor dan masa berlaku SIPI; jenis alat penangkapan ikan; tanggal dan daerah penangkapan; pelabuhan pangkalan; dan jenis dan berat ikan. Sedangkan SKPI diterbitkan oleh Kepala pelabuhan perikanan/pelabuhan umum atau pejabat yang ditunjuk paling lama 2 (dua) hari setelah dilakukan verifikasi terhadap: (a) fotokopi identitas Nakhoda, pemilik kapal, atau yang ditunjuk oleh pemilik kapal; (b) SIPI/surat pendaftaran kapal bagi kapal yang dioperasikan oleh nelayan kecil; (c) Logbook penangkapan ikan; dan (d) Surat Persetujuan Berlayar (SPB).

Permasalahan SHTI terjadi juga dalam hal pemalsuan SHTI-Lembar Turunan yang dilakukan oleh para eksportir. Ironisnya, Direktorat Jenderal Perikanan Tangkap tidak bisa melakukan tindakan kepada para pengolah ikan dan pemasar ikan. Hal ini dikarenakan, kewenangan terkait pengolahan dan pemasaran adalah Direktorat Penguatan Daya Saing Kelautan dan Perikanan, Kementerian Kelautan dan Perikanan. Akibatnya, beberapa eksportir Indonesia tidak bisa menjualkan ikan tuna ke pasar Uni Eropa.

\section{Strategi Perdagangan Tuna Indonesia}

Strategi kebijakan perdagangan tuna Indonesia ke Uni Eropa disusun berdasarkan hasil identifikasi faktor internal dan eksternal. Faktor internal didefinisikan sebagai faktor yang berasal dari dalam lingkungan, yang dalam hal ini adalah sistem pengelolaan baik di daerah dan nasional, sedangkan faktor eksternal adalah faktor yang berasal dari luar, khususnya system pasar Uni Eropa dan regulasinya (Pearce, 1997).

\section{Faktor Internal .}

Faktor internal meliputi kekuatan dan kelemahan. Adapun aspek yang menjadi kekuatan, yaitu: (1) regulasi SHTI. Keberadaan SHTI merupakan jaminan kepastian hukum yang merupakan implementasi atas penerapan EC No 1005/2008; (2) sosialisasi SHTI secara berkala. Direktorat Jenderal Perikanan Tangkap melakukan sosialisasi tiap tahun di pelabuhan-pelabuhan perikanan; dan (3) sistem SHTI berbasis komputer. Pengelola SHTI sudah terlatih dan terkoneksi dengan system SHTI di Uni Eropa. Sementara aspek yang kelemahan, yaitu: (1) keterbatasan jumlah SDM monitoring. Jumlah tenaga pengawas sangat terbatas, sehingga tidak mampu menjangkau yang lebih luas di pelabuhanpelabuhan kecil di sekitarnya; (2) sanksi Logbook lemah. Regulasi Indonesia tidak memuat sanksi, sehingga pengisian data tidak sesuai dengan yang dilaporkan; dan (3) pengurusan izin di daerah lama. Nelayan mengeluhkan lamanya pelayanan SHTI.

Berdasarkan faktor-faktor kekuatan dan kelemahan di atas, maka nilai pengaruh dari faktor yang bersifat strategis sebagai komponen kekuatan (strength) dalam perdagangan tuna ke Uni Eropa adalah regulasi SHTI, sedangkan nilai pengaruh dari faktor yang bersifat strategis sebagai komponen kelemahan dalam perdagangan tuna ke Uni Eropa adalah keterbatasan jumlah SDM monitoring (Tabel 1). Pemberian bobot berdasarkan pilihan responden sesuai tingkat kepentingan dibagi total factor kekuatan dan kelemagan, sementara skala ditetapoan berdasarkan rata-rata tingkat kepentingan yang dipilih oleh responden. Pola ini juga berlaku untuk Tabel 2.

Berdasarkan faktor-faktor kekuatan dan kelemahan di atas, maka nilai pengaruh dari faktor 
Tabel 1. Nilai pengaruh dari faktor yang bersifat strategis sebagai komponen kekuatan dan kelemahan dalam perdagangan tuna ke Uni Eropa

\begin{tabular}{llccr}
\hline No & \multicolumn{1}{c}{ Kekuatan } & Bobot & Skala & \multicolumn{1}{c}{ Skor } \\
\hline 1 & Regulasi SHTI & 0.1952 & 2.6667 & 0.5206 \\
\hline 2 & Sosialisasi SHTI secara berkala & 0.2161 & 2.8333 & 0.6122 \\
\hline 3 & Sistem SHTI berbasis komputer & 0.1054 & 1.5000 & 0.1580 \\
\hline & Total & & $\mathbf{1 , 2 9 0 9}$ \\
\hline No & Kelemahan & Bobot & Skala & \multicolumn{1}{c}{ Skor } \\
\hline 1 & Keterbatasan jumlah SDM monitoring & 0.1744 & 2.6667 & 0.4651 \\
\hline 2 & Sanksi Logbook lemah & 0.1595 & 2.0000 & 0.3190 \\
\hline 3 & Pengurusan izin di daerah lama & 0.1494 & 2.000 & 0.2988 \\
\hline & Total & & $\mathbf{1 , 0 8 2 9}$ \\
\hline
\end{tabular}

yang bersifat strategis sebagai komponen kekuatan (strength) dalam perdagangan tuna ke Uni Eropa adalah sosialisasi SHTI secara berkala, sedangkan nilai pengaruh dari faktor yang bersifat strategis sebagai komponen kelemahan dalam perdagangan tuna ke Uni Eropa adalah keterbatasan jumlah SDM monitoring (Tabel 1).

\section{Faktor Eksternal}

Aspek-aspek yang menjadi peluang yaitu: (1) permintaan tuna di pasar Uni Eropa. Tren peningkatan kebutuhan masyarakat Eropa atas protein ikan, khususnya ikan tuna; (2) Komisi Uni Eropa yang akomodatif. Ketidakmampuan Indonesia dalam menerapkan EC No 1005/2008 karena kondisi Indonesia yang sangat beragam dan dominasi nelayan kecil; dan (3) sistem online data sharing system. Uni Eropa klarifikasi keabsahan SHTI melalui system website sehingga mempercepat komunikasi penindakan yang melakukan pelanggaran. Sementara aspek yang menjadi ancaman, yaitu: (1) perkembangan aturan Uni Eropa. Praktik IUU Fishing dan modusnya semakin beragam, sehingga Uni Eropa mengeluarkan berbagai instrumen untuk mengatasi IUU Fishing tersebut; (2) perkembangan aturan Conservation and Management
Measures (CMM). Organisasi Pengelola Perikanan Internasional (RFMO) sebagai subjek hukum internasional mendukung pemberantasan IUU Fishing dalam aspek pemasaran; dan (3) replikasi Amerika dalam sistem ketelusuran ikan.

Berdasarkan faktor-faktor peluang dan ancaman di atas, maka nilai pengaruh dari faktor yang bersifat strategis sebagai komponen peluang (opportuniy) dalam perdagangan tuna ke Uni Eropa adalah permintaan tuna di pasar Uni Eropa, sedangkan nilai pengaruh dari faktor yang bersifat strategis sebagai komponen ancaman (threat) dalam perdagangan tuna ke Uni Eropa adalah perkembangan aturan Uni Eropa (Tabel 2).

Setelah melakukan analisis terhadap faktor internal dan eksternal, selanjutnya dapat diformulasikan alternatif strategi dengan menggunakan matriks SWOT, yang merupakan kombinasi dari strategi SO, WO, ST, dan WT. perumusan strategi dilakukan dengan mempertimbangkan keempat faktor yaitu kekuatan, kelemahan, peluang, dan ancaman yang telah diidentifikasi. Strategi yang dihasilkan merupakan kombinasi SO (strength-opportunities), ST (strength-threats), WO (weakness-opportunities), dan WT (weakness-threats) yang dirangkum dalam 
Tabel2. Nilai pengaruh dari faktor yang bersifat strategis sebagai komponen peluang dan ancaman dalam perdagangan tuna ke Uni Eropa

\begin{tabular}{llccr}
\hline No & \multicolumn{1}{c}{ Peluang } & Bobot & Skala & \multicolumn{1}{c}{ Skor } \\
\hline 1 & Permintaan tuna di pasar Uni Eropa & 0.2134 & 2.6667 & 0.5691 \\
\hline 2 & Komisi Uni Eropa yang akomodatif & 0.1728 & 2.3333 & 0.4033 \\
\hline 3 & Sistem online data sharing system & 0.1429 & 1.8333 & 0.2619 \\
\hline & Total & & & $\mathbf{1 , 2 3 4 3}$ \\
\hline $\mathbf{N o}$ & Ancaman & Bobot & Skala & Skor \\
\hline 1 & Perkembangan aturan Uni Eropa & 0.1907 & 2.5000 & 0.4767 \\
\hline 2 & Perkembangan aturan CMM RFMO & 0.1728 & 2.5000 & 0.4321 \\
\hline 3 & Replikasi Amerika dalam sistem ketelusuran ikan & 0.1251 & 1.8333 & 0.2294 \\
\hline & Total & & & $\mathbf{1 , 1 3 8 2}$ \\
\hline
\end{tabular}

matriks SWOT (Saaty, 1993). Perumusan strategi pemasaran yang dibangun dengan menggunakan matriks SWOT dapat pada Tabel 3.

Berdasarkan analisis matriks SWOT didapatkan empat macam strategi yang dapat dijelaskan sebagai berikut:

1) Strategi Strength-Opportunities (SO)

Strategi SO adalah strategi menggunakan kekuatan yang dimiliki untuk memanfaatkan peluang yang ada. Berdasarkan kekuatan dan peluang yang diperoleh, maka strategi yang seharusnya, yaitu:

a. Monev implementasi SHTI berkala

b. Pemerataan informasi SHTI di seluruh pelabuhan perikanan

c. Penataan sistem data terpadu

2) Strategi ST (strength-threats)

Strategi ST merupakan strategi memanfaatkan kekuatan untuk menghindari ancaman yang datang dari luar. Strategi ST paling utama, yaitu:

a. Harmonisasi dan sinkorinisasi perkembangan aturan

b. Penyusunan sistem pendataan berbasis IT

3) Strategi WO (weakness-opportunities)

Strategi WO adalah strategi yang meminimalkan kelemahan dengan memanfaatkan peluang yang ada. Strategi WO utama yang bisa dilakukan, yaitu:

a. Peningkatan jumlah pengawasan

b. Revisi regulasi untuk pengisian data yang benar

c. Penataan sistem perizinan di daerah berbasis website

4) StrategiWT (weakness-threats)

Strategi WT merupakan strategi untuk mengurangi kelemahan dan menghindari ancaman. Strategi yang bisa dilakukan, yaitu:

a. Peningkatan jumlah pengawasan

b. Revisi regulasi untuk pengisian data yang benar

Sesuai Tabel 1 dan Tabel 2 dapat dihitung nilai IFAS yang merupakan selisih total nilai pengaruh faktor internal (kekuatan dan kelemahan) yakni sebesar 1,2909-1,0829=0,2079, sedangkan nilai EFAS yang merupakan selisih total nilai pengaruh faktor eksternal (peluang dan ancaman) yakni sebesar 1,2343 - 1,1382=0,0961). Nilai IFAS positif berarti secara kumulatif faktor kekuatan lebih besar dibandingkan faktor kelemahan, dan nilai EFAS positif berarti secara kumulatif faktor peluang lebih besar dari faktor ancaman. Berdasarkan nilai IFAS dan EFAS tersebut dibuat diagram Matrik SPACE seperti pada Gambar 1. 


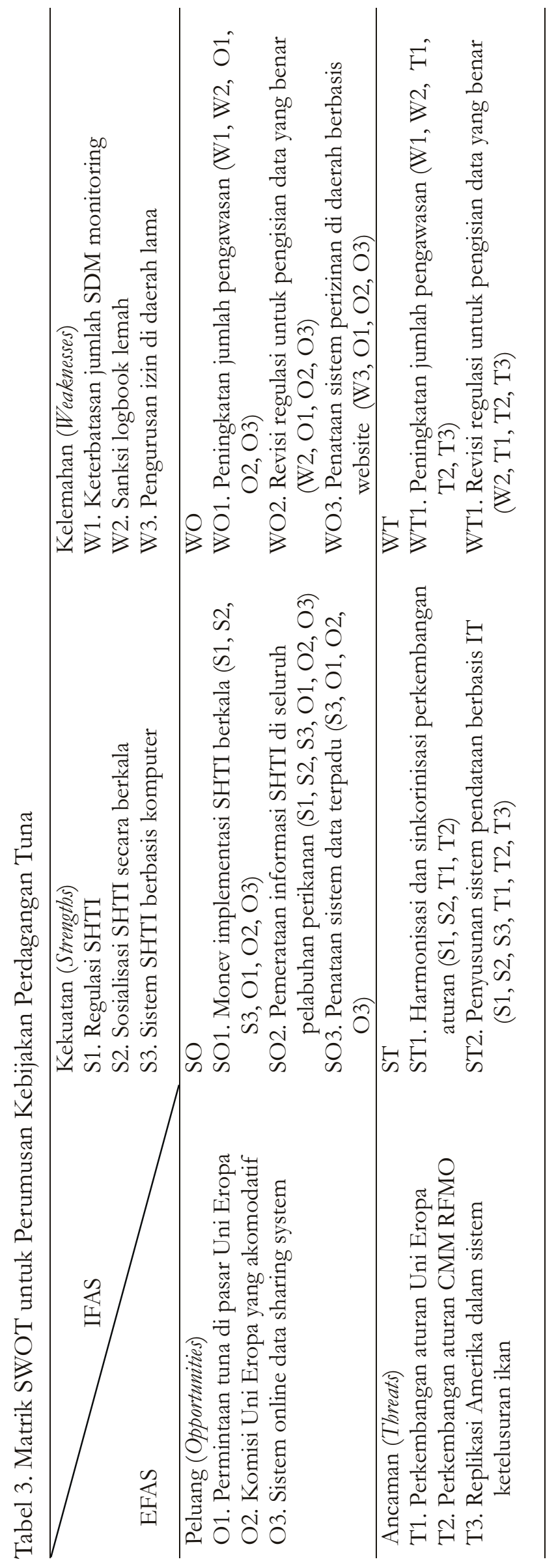




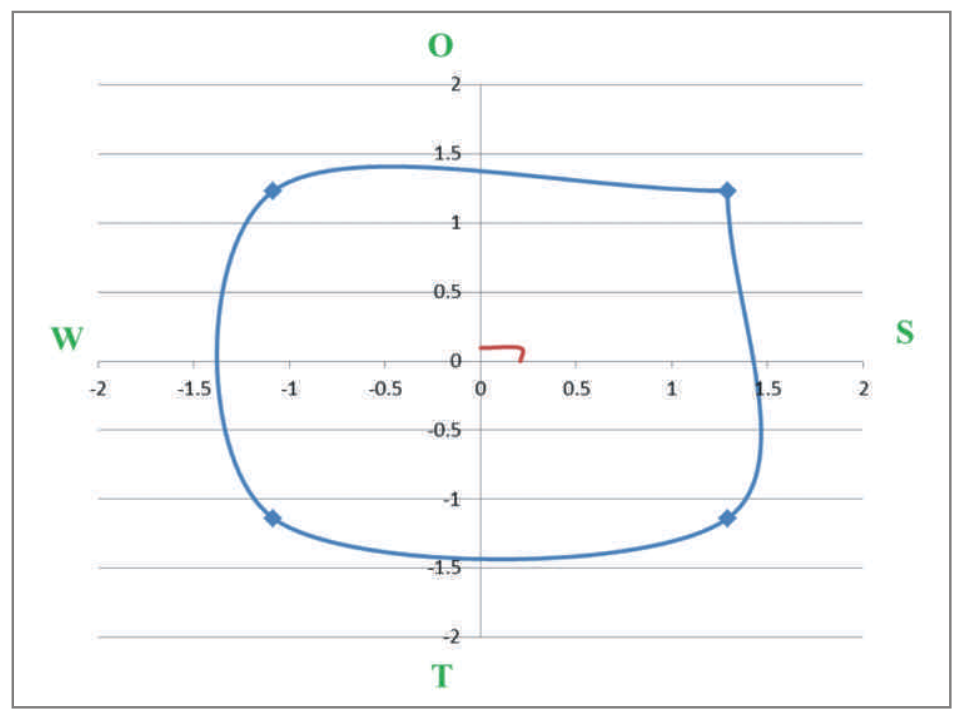

Gambar 1. Diagram matrik space wilayah utara

Berdasarkan Gambar 1 dapat dilihat bahwa strategi perdagangan tuna ke Uni Eropa berada pada kuadran 1. Artinya, posisi ini menandakan perdagangan tuna ke Uni Eropa didukung oleh peluang yang ada. Rekomendasi strategi yang diberikan adalah penguatan strategi, artinya perdagangan tuna ke Uni Eropa dalam kondisi sangat kuat karena didukung oleh peluang yang ada. Oleh karenanya, perdagangan tuna ke Uni Eropa disarankan untuk memperkuat program yang ada. Oleh karena itu, strategi yang terpilih, yaitu: (1) monev implementasi SHTI berkala; (2) pemerataan informasi SHTI di seluruh pelabuhan perikanan, dan penataan sistem data terpadu.

Setelah mengidentifikasi strategi dan alternatif program, langkah selanjutnya adalah menentukan strategi prioritas dalam mendukung perdagangan tuna ke Uni Eropa. Berdasarkan hasil analisis A'WOT tersebut dapat dibuat struktur hierarki seperti dapat dilihat pada Gambar 2. Dari struktur hierarki tersebut diperoleh bobot kepentingan yang menunjukkan prioritas dari tiga alternatif

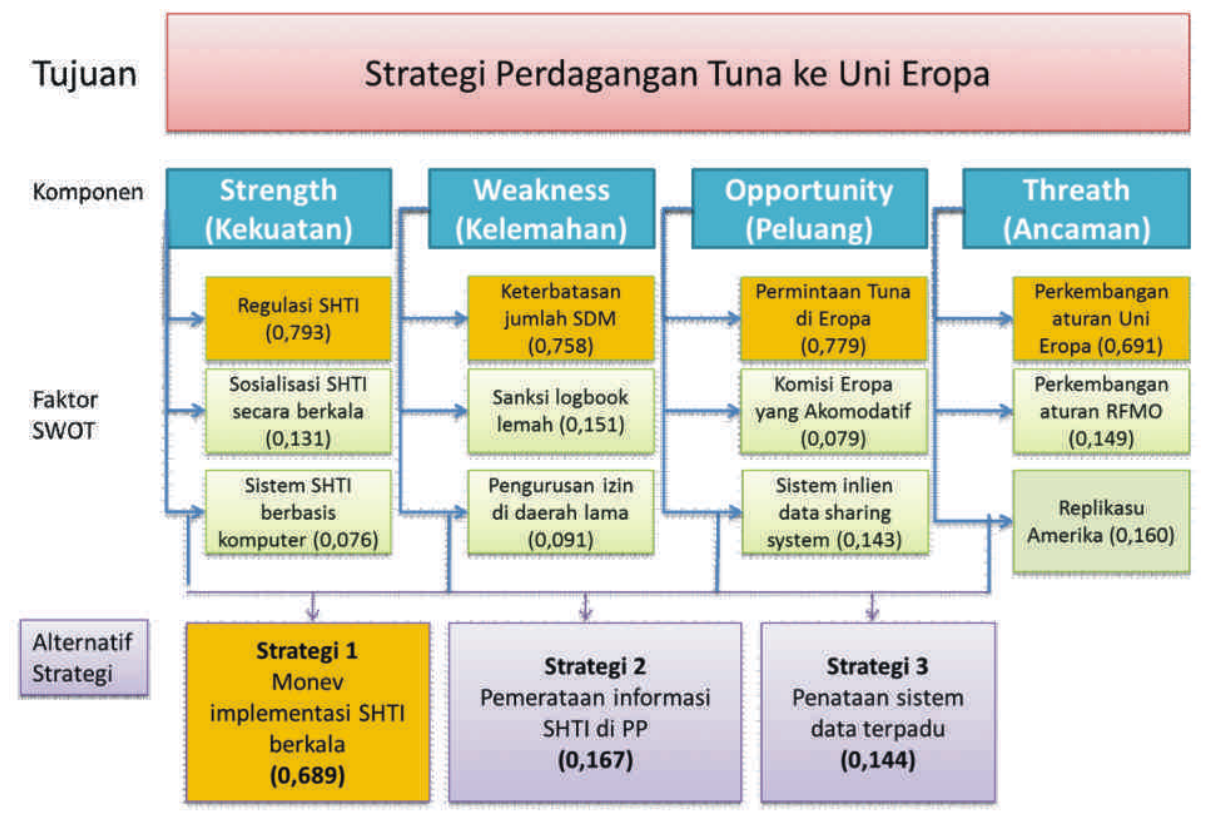

Gambar 2.Struktur hierarki strategi perdagangan tuna ke Uni Eropa 
$\begin{array}{ll}\text { Monev imolementasi SHTI berkala } & .689 \\ \text { Pemerataan informas iSHTI diPP } & .167 \\ \text { Penataan sistem data ter padu } & .144\end{array}$

Gambar 3.Strategi prioritas perdagangan tuna ke Uni Eropa strategi dalam perdagangan tuna ke Uni Eropa.

Berdasarkan hasil analisis A'WOT didapatkan bahwa strategi prioritas pertama adalah monev implementasi SHTI berkala merupakan dengan nilai bobot $68,9 \%$; pemerataan informasi SHTI di pelabuhan perikanan merupakan prioritas kedua dengan nilai 16,7\%; dan prioritas ketiga adalah penataan sistem data terpadu dengan nilai bobot 14,4\%. Strategis prioritas perdagangan ke Uni Eropa tersebut sesuai dengan perhitungan AHP yang ditampilkan pada Gambar 3. Dengan demikian, pemerintah yang dalam hal ini Kementerian Kelautan dan Perikanan harus melakukan pengawasan secara berkala terhadap pelaksanaan SHTI di pelabuhan perikanan, khususnya pelabuhan perikanan yang menjadi basis perdagangan tuna ke Uni Eropa.

\section{REFERENSI}

Branch, T.A. 2008. Not all fisheries will be collapsed in 2048. Marine Policy, vol 32 (2008), pp 38-39.

[DKP] Departemen Kelautan Perikanan. 2007. Program Gemar Makan Ikan: sebagai Strategi Membangun Anak Bangsa Berkualitas, Departemen Kelautan dan Perikanan, Jakarta.

EFTEC (Economic for the Environment Concultancy). 2008. Cost of Illegal, Unreported and Unregulated (IUU)
Fishing in Eropa Union Fisheries. London. European Council (EC) Regulation No. 1005/2008 of 29 September 2008 establishing a community system to prevent, deter and eliminate illegal, unreported and unregulated fishing.

FAO. 2010. The State of World Fisheries and Aquaculture 2010. Roma, Italy.

FAO. 2016. The State of World Fisheries and Aquaculture 2016. Roma, Italy.

Kementerian Perdagangan. 2016. Pasar dan Tren di Uni Eropa. http://inatrims.kemendag. go.id/id/product/detail/pasar-dan-trendi-uni-eropa_189/?market==eu (3 Januari 2017).

MRAG. 2008. The Global Extent of Illegal Fishing. London.

Pearce, R. 1997. Manajemen Strategis. Binarupa Aksara. Jakarta.

Peraturan Menteri Kelautan dan Perikanan Nomor Per.28/MEN/2009 tentang Sertifikasi Hasil Tangkapan Ikan.

Saaty, T.L. 1993. Pengambilan Keputusan Bagi Para Pemimpin. PT. Pustaka Binaman Pressindo: Jakarta.

Worm, B., Edward, B.B., Nicola, B., J. Emmett Duffy, Carl, F., Benjamin S.H., Jeremy B.C.J., Heike, K.L., Fiorenza, M., Stephen, R.P., Enric, S., Kimberley A.S., John J.S., Reg, W. 2006. Impact of Biodiversity Loss on Ocean Ecosystem Services. Science, vol 314, pp: 787-790. 